Jessica Imbach*

\title{
Variations on gui and the Trouble with Ghosts in Modern Chinese Fiction
}

DOI 10.1515/asia-2015-1013

\begin{abstract}
Ghosts appear in a great number of fictional works from the early modern period to the present. Yet, to this date no systematic study of this very heterogeneous textual corpus has been undertaken. This paper proposes as a useful starting point a review of figures and discourses of spectrality, mainly in Republican-era literary and critical texts, that focuses in particular on the different meanings and usages of the term gui, "ghosts". A better understanding of gui helps us not only to distinguish different approaches towards spectral figures, which do not necessarily always operate on a secular-religious binary, but also brings the entangled dynamics of the aesthetic and the political in modern Chinese ghost fiction into sharper focus.
\end{abstract}

Keywords: ghosts, ghost fiction, modern Chinese fiction, history, literary discourse

\section{Introduction}

In Chinese literature, ghosts have a long and varied history. As figurations of cosmological (dis-)order and both sexual and temporal transgression, among other things, ghosts figure not only prominently in a variety of genres, but also often attracted the disdain of state ideologues and religious reformers. However, it is only at the beginning of the twentieth century that ghosts, both as religious and literary subject matter, become a symptom of national crisis and condemned to decompose alongside the "Confucian rubble" that the May Fourth iconoclasts were eagerly shoveling into the dustbin of history. Culminating in one of the most famous slogans of Chinese socialist culture "The old society turned humans into ghosts, the new society turns ghosts into humans!", ${ }^{1}$ the history of modern

1 This line is from the revolutionary folk opera “The White-haired Girl” (Baimaonü 白毛女, 1945), which was adapted numerous times for stage and screen and eventually also became one of the "model operas" (yangbanxi 样板戏) during the Cultural Revolution. For a history of this play see: Meng Yue 1993.

*Corresponding author: Jessica Imbach, University of Zurich, Asien-Orient-Institut, Zürichbergstrasse 4, 8032 Zürich, Switzerland. E-mail: jessica.imbach@aoi.uzh.ch 
Chinese literature has primarily been one of "ghost beating” (dagui 打鬼). ${ }^{2}$ While classical Chinese literature boasted a motley inventory of supernatural beings and reveled in accounts of marvelous journeys across space and time, modern Chinese literature was conceived of as first and foremost centered on the experience of real life and the common people that elite culture had chosen to ignore for millennia; ghosts made way for humans and the fantastic and the strange were increasingly replaced with mimetic modes of writing. Yet, ghosts have stubbornly refused to leave the scene. Ghosts appear not only in contemporary fiction by Su Tong 苏童, Han Shaogong 韩少功, Can Xue 残雪, Jia Pingwa 贾平凹 and Mo Yan 莫言, but also in fiction from the 1920s to the 1940s by Shanghai writers such as Shi Zhecun 施蛰存, Mu Shiying 穆时英 and Shi Jimei 施 济美, in revolutionary Yan'an novels by Zhao Shuli 赵树理 and Ouyang Shan 欧阳 山 and even in highly ideological fiction from the 1960s such as Zhou Libo's 周立 波 short stories. And although the body of new ghost fiction markedly diminished during the twentieth century, ghostly figures and tropes of spectrality have actually become more numerous as not only the familiar ghosts kept reappearing, but were also joined by the ghosts of Western gothic fiction, Freudian psychoanalysis, and many more.

How can we bring this diverse body of imaginative ghost writings into sharper focus? Previous studies examining ghosts in Chinese literature have proposed the concepts of "phantasmagoric realism" 3 or "logic of the phantasm", 4 but both apply chiefly to fiction from the late twentieth century and focus on ghosts as figurations of trauma, memory and history. ${ }^{5}$ While I do not refute the relevance of these issues, it is important to note that the various usages and meanings of ghosts in modern Chinese fiction do not exhaust themselves in a spectral economy of repression and return. Ghosts appear throughout the modern period both as a rhetorical trope and as real ghosts, although non-figurative usages rarely imply an ontological claim and are rather invoked to make a philosophical or aesthetic proposition. My interest in studying these different appropriations of ghosts lies not so much in discerning subversive from dominant usages, which do in fact not always coincide with the conceptual distinction between the figurative and the non-figurative, as in analyzing how both ghosts and "ghosts" become bound up with specific entanglements of the aesthetic and the political.

$2 \mathrm{Hu}$ Shi 胡適 2003b.

3 David Wang 2004: ch. 8.

4 Jianguo Chen 2009: ch. 2.

5 Other notable studies of modern Chinese ghost fiction include: Wedell-Wedellsborg 2005; Xiao Xiangming 2006; Ng 2007. 
From a cursory survey of texts featuring ghostly figures and constellations of haunting from the early twentieth century to the present we can make two observations. First, there is no set of generic conventions or recurring motifs that would allow us to systematically assign texts to one specific genre of ghost literature (e.g. zhiguai, gothic novel) nor do these texts amount to a modern Chinese literature of the fantastic. In this paper I therefore use the terms ghost literature and ghost writings both to highlight the relationship of these diverse texts to each other and to avoid genre confinement, and its normative valences, not least because both ghosts frequently challenge and confuse neat distinctions between high-brow and low-brow fiction, vernacular and classical idioms.

Secondly, these ghost writings are rarely treated as canonical and are often conveniently placed outside the purview of studies on China's literary modernities, even though some were overwhelmingly popular at the time they were published such as Xu Xu’s “Ghost Love” (Guilian 鬼戀, 1937). However, what does unify many of these texts is that they are often criticized for fostering religious superstitions, anachronistic world-views, misogynism and anti-nationalistic sentiments, sometimes all of the above at once. Thus it is possible to broadly define these very diverse imaginative writings in terms of their dangerous affinities to increasingly suspect ideologies, although social realist fiction in particular tends to vehemently declare an anti-ghost stance. This criticism hinges on a strongly politicized notion of gui 鬼 (“ghost”). How does gui become important? And how is gui employed as an aestheticopolitical term? In what follows, I propose some tentative answers to these questions by analyzing usages and critiques of gui in mainly Republican-era sources. ${ }^{6}$ I also consider some hitherto rarely discussed literary texts that in some way critically engage with an increasingly gui-hostile literary environment.

\section{Locating gui: debates, critiques and literary positions}

Although ironclad distinctions between ghost, phantom, revenant, spook, spirit, etc. would be difficult to make in any language, in modern Chinese "ghost" is

6 I do not discuss here the (religious) iconography of ghosts, although it too would certainly add to our understanding of the appropriations of gui in modernization discourse. However, my primary interest lies in understanding the negotiations with and intellectual debates on literary ghosts that have not yet received the same attention as their visual counterparts, as for instance the globally circulated ghosts of Hong Kong cinema. 
conventionally translated as gui, while hun 魂, hunpo 魂魄 and youling 幽灵 refer more frequently to the immaterial soul, the spirit, or metaphorical meanings derived thereof. While the compound guishen 鬼神 (ghosts and gods) already suggests that even the divine shen are more closely associated with the ghostly than the gods in the Graeco-Roman tradition, the hulijing 狐狸精, “were-fox”, the yuanhun 冤魂, “vengeful spirit”, the jiangshi 僵尸, “zombie” and the myriad of circumstantially determined ghosts like the shuigui 水鬼, "ghost of the drowned", and many more all belong to the at times dangerous, at times jocular world of supernatural beings that have no single equivalent in English vocabulary. Earliest usages of the character gui suggest that it could mean both foreign in the sense of non-Chinese as well as in the supernatural sense of not belonging to the world of the living. ${ }^{7}$ While the meaning of the character is highly debated, the Chinese word gui has been shown to be a derivative of the verb wei 威, “awe inspiring". ${ }^{8}$ From a literary historical perspective, the term hun is more important, especially in the compounds huanhun 还魂, “returning soul” or “revenant”, and yuanhun 冤魂, “vengeful spirit”. 9 But because gui had over time acquired a number of derivative meanings, often derogatory in nature, and are also more closely associated with religious practices than other ghost figures, May Fourth secularizers singled out gui as their primary target of attack and not, for instance, a belief in hun.

A particular thorn in the eyes of the “New Youth” (Xin Qingnian 新青年) literati was the “Shanghai Spiritist Society” (Shanghai lingxuehui 上海灵学会) and their experiments with such things as spirit calligraphy (jizi 乩字), spirit painting (jihui 乩绘 or jihua 乩画), and spirit photography (linghun zhaoxiang 灵魂照相). In their attacks neither hun nor youling appear and instead gui take the center stage. Lu Xun 鲁迅 writes in 1918:

\footnotetext{
Nowadays, there is a whole group of people talking about ghosts [guihua 鬼话]. They hate science, because science teaches us reason and understanding as well as a clear thought process, which doesn’t allow for any aimlessness [guihun 鬼混]. [...] They even go as far as to propose the death sentence for science, and yet still unexpectedly invoke the two teachings. That is why on a boxer pamphlet it is clearly stated: "Master Confucius and Celestial Master Zhang [famous Daoist hermit] are sending you their words from Shandong, spread it fast, there is no false word!” [...] In my opinion, to rescue this China, which "is about to be divided and its people extinct" the method of "Master Confucius and Celestial Master Zhang sending word from Shandong” is completely inappropriate. Only science can oppose this ghost talk! Real science cannot be easily dismissed! ${ }^{10}$
}

7 Mu-chou Poo 2004.

8 I thank Prof. Wolfgang Behr for his helpful comments on this matter.

9 The semantics of gui and hun are also discussed in Zeitlin 2007: 4-5.

10 Lu Xun 1987a: 298-302. 
Also, in contrast to earlier critiques of various Chinese ghost beliefs, their anti-superstition campaign did not distinguish between the political, the social, and the cultural. Indeed, under the fiery pen of these reformers a new gui-ghost appeared that was not only the antithesis of the secular and the scientific, but a cultural obstacle in the mind of China's people that they would have to overcome to become a modern nation. ${ }^{11}$ Gui became a master signifier that encompassed not only all old forms of ghostly literary and non-literary discourses, but also produced a plethora of new figurative uses. The old ghosts were joined by “living ghosts” (huogui 活鬼) such as “foreign devils” (yanggui 洋鬼), “opium ghosts” (yangui 烟鬼), “romantic ghosts” (fengliugui 风流鬼, i. e. brothel clients) and most infamously the "Japanese devils" (riben guizi 日本鬼子). While this "living ghost" rhetoric was not new in itself, a semantic shift in its use was taking place. One often cited example is Hu Shi's 胡适 list of China's five ghosts: poverty, disease, ignorance, corruption and chaos. But he uses gui in this text synonymously with choudi 仇敌, “enemy”. Gui signifies here no longer simply a moral judgment, but the much graver accusation of obstructing China's modernization. ${ }^{12}$

A strong interest in gui is further evidenced in linguistic and paleographic scholarship of the time. Zhang Taiyan 章太炎 (in 1907) and Shen Qianshi 沈兼士 (in 1935, translated into English in 1936) pushed for a worldly interpretation of the character's semantics. ${ }^{13}$ Shen especially argued that gui in its earliest usages was not primarily and only in very limited contexts used as ghost or spirit and should rather be read as referring more often to the worldly realms of wild animals, foreign tribes, and human feelings of fear and disgust. Although Shen's scholarly work can be situated within the movement for the "organization of national heritage” (zhengli guogu 整理国故) around Hu Shi and Gu Jiegang 顾颕刚, Shen's work on the character gui was not directly driven by any political agenda.

In literary circles, however, ghosts were a more politically charged subject matter. In a short study on ghosts in Shakespeare's works, the literary critic Liang Shiqiu 梁实秋 sarcastically remarks that his leftist colleagues were so fervently against ghosts that if Shakespeare were alive in China at this moment his ghosts would not be allowed on stage. ${ }^{14}$ And in the editorial to the ghost story special issue (Gui gushi zhuanhao 鬼故事专号)

\footnotetext{
11 Chen Duxiu 陈独秀 1992.

$12 \mathrm{Hu}$ Shi 胡適 2003a.

13 Zhang Taiyan 章太炎 1982; Shen Jianshi 沈兼士 1986.

14 Liang Shiqiu 梁实秋 1936.
} 
of the “Analects Fortnightly" (Lunyu banyuekan 论语半月刊), in which Liang's article appeared, the editor Shao Xunmei 邵洵美 disparagingly concludes that anti-superstition campaigns had dealt a nearly fatal blow to ghosts in literature as well, although he was convinced that ghosts indeed should have a place in modern fiction. ${ }^{15}$ But to literary reformers ghosts were not simply a problematic subject matter. They also symbolized China's literary heritage as a whole - a sentiment that is astutely captured in Lu Xun's caricature of Chinese literature as conveying nothing but the "optimism of zombies". ${ }^{16}$

However, gui could to a certain degree also be of scholarly interest. The rediscovery of the Qing novel "What literary reference is this?" (He dian 何典, Zhang Nanzhuang 张南庄, 1879) by the leftist intellectual Liu Bannong 刘半農 is particularly illuminating in this respect, because the novel is not only set in the ghost world, but actually uses the ghost world as a pretext for its excessive creation of neologisms with gui as affix. ${ }^{17}$ While Liu Bannong found it necessary to censor sexually explicit expressions from the novel, he did not take issue with its ghost discourse, as Zhang's ghost parody relies chiefly on the lexical ambiguity of gui as both "ghost" and "non-sense". As a signifier of irreverence towards Confucian literary practices and its scrupulous deference to canonical works (as the title puns on), gui are here read as part and parcel of a popular literary practice that resisted this dogmatic and calcified establishment and serve (rightly or not) as historical proof of a proto-vernacular literary tradition. ${ }^{18}$

At the same time, there was a renewed interest in the early Qing novel “A Tale of Ghost Beheading” (Zhangui zhuan 斩鬼传, 1688, Liu Zhang 刘璋), ${ }^{19}$ in whose generic lineage He dian was placed, and the sub-genre of ghost satire more generally. ${ }^{20} \mathrm{~A}$ number of new imitative works appeared by writers of

15 Shao Xunmei 邵洵美 2012. For a more detailed analysis of this ghost story special issue see my own article (2014).

16 Lu Xun 1987c:12.

17 In fact, the novel had never been as obscure as its rescuers Liu Bannong and Lu Xun thought, because apart from the original at least four editions had already been in circulation prior to Liu's modern edition from 1926. See Altenburger 2001.

18 Further discussion of He dian can be found in Wang 1997 and Altenburger 2001.

19 This novel was reprinted at least twice during the socialist period prior to the Cultural Revolution. In a brief summary accompanying the 1959 edition, the editors point out that fiction such as Zhan gui zhuan helps renew the contemporary reader"s appreciation of the "value and beauty" (kegui ke'ai 可贵可爱) of the present, while they also freely acknowledge that they excised vulgar expressions, "a common problem in popular fiction of the time". The novel has been translated into German (du Bois-Reymond 1923) and French (Danielle Éliasberg, 1976).

20 David Wang describes this genre as "comic ghost fiction”, see Wang 1997: 205. 
very diverse backgrounds. Probably the most famous examples are Zhang Henshui's 张恨水 “New Account of Ghost Behading” (Xin zhan gui zhuan 新斩鬼传, 1926) 21 $^{21}$ and Zhang Tianyi’s 张天翼 “Ghostland Diary” (Guitu riji 鬼土日记, 1931). ${ }^{22}$ Both novels draw on a similar logic of tragicomically invoking the underworld and its myriad of strange figures and customs to create a sociopolitical satire of the present. Liu Shengya's 刘盛亚 ${ }^{23}$ novel “Gates of Hell” (Diyumen 地狱门, 1949) can also be put into this group of works, although Liu wrote a this-worldly social critique. "Gates of Hell" derives its title from the Mulian mystery plays, which chronicle the monk Mulian's adventurous travel to the underworld to save his mother. Centered on a peasant women, who marries into a wealthy household, Mulian's quest to the underworld serves in "Gates of Hell”, however, not as a backdrop to playful literary satire, but rather anchors a harsh social critique in the allegorical horizon of cosmological disorder.

Parallel to this line of mostly satirical gui allegories developed a strand of leftist ghost literature that targeted specific political enemies. Here gui designate both an ideogeographical distinction between civility (hua 华) and barbarity ( $y i$ 夷) and ideological difference, which also helps explain why the famous "specter" from the opening line of "The Communist Manifesto" (1848) has never been rendered as gui in Chinese translations. ${ }^{24}$ One example is Wang Lan’s 王蓝 “Tales from Ghost City” (Guicheng Ji 鬼城记, 1944) that captures in short vignettes the author's experiences during four years in Tianjin, bearing witness to "the beautiful and majestic mountains and rivers turning into heaps of skeletons and lakes of blood". ${ }^{25}$ Ouyang Shan's novel "Ghost Nest” (Guichao 鬼巢, 1936) is an interesting hybrid in this sub-genre, because the ghosts of the title refer both to the Guomindang government and to the Communist victims of a mass assassination, who are now haunting an old theater. Although Ouyang begins his novel with the narrator insisting that he never

21 Zhang makes explicit reference to „What literary reference is this?” in the preface.

22 "Ghostland Diary" actually combines elements of both ghost satire and (fantastical) travel literature such as Jinghua yuan 镜花缘 (“Flowers in the Mirror”, 1827, Li Ruzhen 李汝珍) and Laocan youji 老残游记 (“The Travels of Lao Can”, 1907, Liu E 刘鸣), especially in its use of the figure of the uninitiated traveler, who embodies the foil of normalcy to the foreign and exotic locale on literary exhibition (in this case a living person, temporarily transported to the world of the dead).

23 Liu Shengya”s (1915-1960) literary oeuvre is today almost completely unknown. To Xiao Xiangming 肖向明 goes the credit for rescuing “Gates of Hell” from complete archival obscurity (see Xiao 2009, where he also discusses among other works the novels of both Zhangs), but a synopsis of some of Liu's works can also be found in Yang Yi 杨义 1998: 131-138.

24 The first full translation into Chinese by Chen Wangdao 陈望道 was published in 1920.

25 Wang Lan 1944: 63. 
liked "mysterious, monsterous and strange things" 26 the supernatural connotations of gui carry considerable narrative momentum, as when, for instance, the ghosts visit the protagonist Gao Gang's 高刚 dreams.

These ghost satires and political allegories often very openly display and even boast their own fictionality, which protected them from the more vitriolic criticism other ghost writings faced. Particularly troublesome, especially to leftist critics, were figures of female spectrality, which are also in modern fiction a prominent theme. Taking the form of femme fatale revenants, beautiful corpses, and suicidal brides, gendered figures of death and repetition are especially well-known from the works of neo-sensationalists such as Shi Zhecun 施蛰存 (e.g. Modao 魔道 “Devil’s Way”, 1931; Yechai 夜钗 “Yaksha”, 1932) and $\mathrm{Mu}$ Shiying (e.g. Hei Mudan 黑牡丹 “Black Peony”, 1934), but also appear in so-called popular (tongsu wenxue 通俗文学) fiction from the 1940s by female authors such as Shi Jimei 施济美 (e.g. Fengyi Yuan 凤仪园 “Fengyi Garden”, 1947; Guiyue 鬼月 “Ghost Month”, 1948) and Tang Xuehua 汤雪华 (Mi 谜 “Riddle”, 1945). While historically the "hyper-femininity” of the female phantom is a result of the yin-position that both women and ghosts occupy within the "natural and moral order" ${ }^{27}$ of the world, her yinness is in the modern period intensified to now also represent "the nearly ten thousand years of injustice and hardship that women have endured."28 In “Ghosts and Women” (Gui yu nüxing 鬼与女性, 1936) the leftist literary critic Ma Zihua 马子华 notes that

[...] the fact that ghosts [gui] are predominantly female is nothing extraordinary and has reasons that can be studied. [...] that 'ghosts' are mostly female, this is the crystallization of a very ancient mentality, the product of a feudal system..$^{29}$

Rather crudely equating cultural representations with social realities he argues that female phantoms give evidence to a misogynist culture that has over centuries systematically victimized, fetishized and demonized woman. And he concludes with the confident prediction that in the coming socialist and genderequal society ghost stories will seize to exist completely. It is thus not very surprising that Ma has nothing to say on the ghost fiction written at his time. ${ }^{30}$

26 Ouyang Shan 1988b: 594.

27 Zeitlin 2007: 17.

28 Zhou Zuoren 1992: 469-70.

29 Ma Zihua 1936: 957.

30 What Ma uses as primary reference are interestingly two ghost tales that circulated "twentyfive years ago" in the "provincial capital of Yunnan”, Ma Zihua 1936: 955. 
Just like Shanghai modernist and popular fiction as a whole was largely ignored by leftist critics, such "ghost talks" are within the temporal logic of Ma's developmentalist culture theory nothing but the last remnants of a vanishing world soon to be replaced by a literature of the "living" (huo ren de hua 活人的话). ${ }^{31}$

Arguably one of the most important ghost novels of this period is $\mathrm{Xu} \mathrm{Xu}$ 's "Ghost Love", which was first published in the January and February issues of “Cosmic Wind” (Yuzhoufeng 宇宙凤) in 1937, but revised and substantially extended for its first book publication in 1939 and subsequent re-prints. ${ }^{32}$ Thematically, "Ghost Love" is a rather idiosyncratic take on the generic literary formula of “revolution plus love“ (geming jia lian'ai 革命加恋爱), which was also playfully adapted by other Shanghai writers of the period and not an exclusively leftist domain. ${ }^{33}$ But "Ghost Love" inverts this popular theme by suspending the romantic utopianism of the genre in a poetic world of fragile stasis, in which love remains unfulfilled and revolution far out of reach. While readings of "Ghost Love" have tended to focus on the "love" part in the title - something $\mathrm{Xu}$ himself criticized for being as trivial as "standing in front of a statue of Rodin and only looking at the reproductive organs"34 - little attention has been given to Xu's choice of gui and its prominence within the narrative. A detailed discussion of "Ghost Love" is beyond the scope of this paper, but it is important to note that $\mathrm{Xu}$ wrote this novel not long after the publication of the Analects double special issue on ghost stories, in which a very different text of Xu's appeared, the short drama “Ghost Play” (Guixi 鬼戏, 1936). ${ }^{35}$ This play is divided into three short dialogs between "ghost" and "human" that are set in the "past", "recent past" and "present". While this formulaic structure is repeated in "Ghost Love", where the female protagonist refers to herself only as "ghost" and calls the narrator "human", "Ghost Play" draws on gui in a much more expected way as an allegory on foreign intervention and military aggression, which the Chinese "human" is incapable of fighting off. A similar allegorical reading of "Ghost Love" yields a very different interpretation: in matters of politics gui are the enemy, in matters of aesthetics gui embody an intense (poetic) desire.

$31 \mathrm{Lu}$ Xun 1987b: 13.

32 In 1941 "Ghost Love" was also turned into a movie. For a discussion of the novels various cinematic adaptations see Chen Qin 2010.

33 Liu Jianmei 2002.

34 Afterward to the 1943 edition of "Ghost Love" (no page numbers).

35 In the "Complete Works of Xu Xu" this drama is dated to 1934. That same year he also wrote the essay “On Ghosts and Divinities” (Tan guishen 谈鬼神), in which he expresses his concern over the revival of ghost beliefs, which he reads as a sign of China's weakness. 
"To end as an ugly corpse is the fate of every beautiful human. That is why in the human world there is no beauty and nothing can be called beautiful. Because no matter how beautiful something is, it is in the end always ugly."

"But ghosts then could be at best like humans and not more beautiful."

"You are not a ghost, how could you know?"

“And you are not human!”

"But I used to be a human, an extremely lively human."

"I think you still are."

She looked up to the sky: "Nature is truly beautiful."

"The night is especially beautiful."

"Let me ask you, do you think the night is more beautiful than the day?"

"I do."

"And the night belongs to ghosts." 36

In Xu's spectral literary aesthetic the political realities of the modern world recede into a mystical and exotic dreamscape and nature again becomes an object of poetic contemplation. Although critics would later single out "Ghost Love" as exemplary of $\mathrm{Xu} \mathrm{Xu}$ 's literature of "escape, intoxication, transcendence, fatalism and surrender", ${ }^{37} \mathrm{Xu} \mathrm{Xu}$ was certainly not without political convictions, but rather tried to (re-)establish a distinction between politics and art, between gui as enemy and gui as loved one.

And it was not only a romanticist writer who took issue with the restrictive aesthetic paradigms that these discussions on ghosts in literature exemplified. In a remarkable short story entitled "The Buffalo" (Niu 牛, 1947) by the female writer Yuan Changying 袁昌英, who is today best known for her play “Southeast Flies the Peacock" (Kongque dongnan fei 孔雀东南飞, 1929), animals and ghosts are linked to a private and imaginative sphere that can no longer communicate itself to the new human world of language. While religious rituals and attendance of the Mulian play are portrayed as rather passively observed, the intimate bond between an old buffalo and the protagonist, a young boy called En En 恩恩, stands for a different kind of spirituality disappearing from a world, in which "the new age was slowly entering China's every corner". 38

36 From the first edition, reprinted in Wu Huanzhang (ed.) 1996: 376.

37 This is from a conference report on Xu Xu entitled: "Butterflies, Dreams, Xu Xu" (HudieMeng - Xu Xu 蝴蝶·梦.徐訏), published in 1948 in the Tianjin Dagong bao 天津大公报, qtd. in Chen Xuanbo 2004: 316.

38 Yuan 1947: 10. 
Such subtle and more nuanced voices were nevertheless becoming rare. Ouyang Shan’s novel “Uncle Gao” (Gao Ganda 高干大, 1946), written in the highly ideological cultural milieu of Communist-controlled Yan'an, foreshadows how after the founding of the People's Republic of China the term gui was more systematically pitted against the new socialist society. Ouyang's novel recounts the trials and tribulations of its eponymous protagonist, who is put in charge of a rural collective. Of all the difficulties he faces (stubborn bureaucrats, ideological hardliners, ignorant peasants), none is greater or treated at greater length than a group of evil shamans and sinister dream diviners, who are threatened by Gao Ganda's plan to establish a healthcare system within the collective. It is no surprise that Gao Ganda ultimately emerges victorious by killing the vicious mastermind behind the superstitious conspiracy, although he is probably the last socialist hero who is still granted the ability to fear ghosts. ${ }^{39}$ After 1949, ghosts disappear completely, while religious rituals and ghostlore remain occasional sidenotes in fiction and cinema from the seventeen-year period (1949-1966). However, in nearly all the texts I know of these are presented as symptoms of feudal cruelty and "superstitious" ignorance. A very incisive cinematic example is the critique of ghost marriages in the "The Red Detachment of Women” (Hongse niangzi jun 红色娘子军, 1961, dir. Xie Jin 谢晋), where the second female lead character Hong Lian 红莲 is forced to share her marital bed with a wooden replica of her deceased husband's corpse. Under Xie Jin's skillful direction, this image deftly captures both the rigor mortis of tradition as well as the physical and emotional pain such traditions continue to inflict.

From a literary-historical perspective, the most interesting development in these years is the transformation of the ghost tale itself into a pedagogical genre through both adaptation and re-interpretation. An example of the former is “Strange Tales from the Literacy Campaign” (Saomang zhiyi 扫盲志异, 1963), in which Zhou Libo tells the story of a conservative peasant who suspects his daughters' teacher of improper conduct. The implication is here that the father's apprehension towards co-education is not only misguided, but "unnatural" in a sense that actually closely approximates premodern conceptions of $y i$ (异 “strange”). The most well-known ghost stories of the socialist period, however, are the "Stories About not Being Afraid of Ghosts" (Bu pa gui de gushi 不怕鬼的故事, 1961). This collection of often slightly abridged or altered classical ghost stories was edited by the Chinese Academy of Sciences (Zhongguo kexue yuan 中国科学院 ${ }^{40}$ on request by Mao himself, who also

39 Ouyang 1988a: 1551-1552, 1705.

40 Since 1977 this is the Chinese Academy of Social Sciences (Zhongguo shehui kexue yuan 中国 社会科学院). 
personally corrected the first draft of He Qifang's 何其方 introduction, in which he explains the relevance of ghost stories in the following:

The ghosts [gui] of these stories do not exist, but in this world there really are numerous things similar to ghosts. These may be big, such as imperialism and its lackeys in various countries, modern revisionism, catastrophic natural disasters and certain members of the class of landlords and the bourgeoisie, who have not yet been properly reformed and are trying to regain their authority in certain low-level organizations to restore the old order. Or they may be small, such as some ordinary trouble or a mistake at work, etc. [...] The only difference between them and ghosts is that they really exist, whereas ghosts do not exist. ${ }^{41}$

Ghost stories are here weaponized to target gui as embodiments of both ideological enemies and personal difficulties. But "Stories About not Being Afraid of Ghosts" owes its pivotal role in the history of modern Chinese ghost fiction not only to the fact that it updates and expands the referential scope of an already well-established anti-gui rhetoric. It also puts the ghost story itself in the service of the state by turning "superstitious" textual artifacts into blueprints of antirevolutionary struggle. ${ }^{42}$ As such, it is an early harbinger to the collective and institutionalized "ghost" prosecutions in the years to follow, which continue to haunt China today. Su Tong 苏童, for instance, imagines a scenario of counterhaunting in his short story “How the Ceremony Ends" (Yishi de wancheng 仪式的 完成, 1989), in which a folklorist "re-discovers" an ancient ritual of human sacrifice that can be read as a re-enactment of the prosecution of "ox ghosts and snake spirits” (niugui sheshen 牛鬼蛇神) during the Cultural Revolution. "Stories About not Being Afraid of Ghosts" did not only renew the relevance of ghost stories to modern China, it also demonstrated the high malleability of (literary) ghost discourses and thus played a contributing role to the emergence of critical ghost fiction in the post-Mao period.

\section{Coda}

To this day, China is the only country in the world that has an official ban on ghosts (and other supernatural creatures, for that matter) in movies in place.

41 I modified the official English translation so as to adhere closer to the original text. Zhongguo kexueyuan wenxue yanjiusuo 1961: 4-5; The Institute of Literature of the Chinese Academy of Sciences 1961: 4-5.

42 Twenty six of the sixty six stories included in the $2^{\text {nd }}$ edition from 1961 were modified. In some cases these are minor changes such as a modified or added title. In other cases, the editors excised large portions of the original text. 
Although there are domestic productions that have managed to bring some ghosts back to the silver screens, their appearance is most often couched in narratives that offer some "rational" explanation for the supernatural events and appearances. ${ }^{43}$ Or they cater to the state's global culture agenda, as in the most prominent case of the movie franchise “Painted Skin” (Huapi 画皮, 2008, dir. Gordon Chan 陈嘉上; Huapi 2, 2012, dir. Wu Ershan 乌尔善). Although ghost censorship in literature has ceased almost completely, ${ }^{44}$ ghosts are still a politically sensitive subject matter and continue to be appropriated and re-interpreted both in political rhetoric as well as in literature. ${ }^{45}$ While for instance in the latest and heavily expanded edition of "Stories About not Being Afraid of Ghosts" from 1999 gui are yet again invoked to discredit enemies of "socialism with Chinese characteristics”, 46 Yu Hua’s 余华 harsh critique of contemporary Chinese society in “The Seventh Day” (Di qi tian 第七天, 2013) is delivered by an all ghost cast. Although gui developed throughout the twentieth century into a shorthand for everything that obstructed China's development, this process also entangled literary ghosts in a dynamic web of competing aesthetic projects and (cultural-)political discourses, which our histories and readings have yet to fully recognize.

Acknowledgment: This research was conducted with a Marie Heim-Vögtlin grant from the Swiss National Science Foundation.

Funding: Schweizerischer Nationalfonds zur Förderung der Wissenschaftlichen Forschung, (Grant/Award Number: “PMCDP1_157969”).

43 A short history of ghost censorship in Chinese cinema can be found in Laikwan Pang 2011. Some examples of PRCh horror movies are discussed in Li Zeng 2009.

44 There are rumors that the online hit novel “Ghost Blows out the Candle” (Gui chui deng 鬼吹 灯, 2006, Tianxia Bachang 天下霸唱 (Zhang Muye 张牧野)) had to be altered prior to its hardcopy publication. True or not, it is interesting that this discourse of ghost censorship continues, if only to add panache to a commercial novel.

45 I have focused here mainly on literary texts, but similar cases can also be found in other fields of cultural production. A good example is the heated debate on the figure of Li Huiniang in modern operatic adaptations of „Red Flowering Plum“ (Hongmei ji 红梅记). See: Maggie Greene 2012; Zhang Lianhong 张炼红 2013.

46 „As we are approaching the new millennium, those practices that the May Fourth cultural avant-gardists Lu Xun and Chen Duxiu already rebuked as „ghostly“ (guidao 鬼道) and „demonic spirited“ (yaoqi 妖气) such as false qigong and false science, are regaining the upper hand. Under the pretense of promoting traditional ethnic culture and health through physical exercise, [these practices] deceive the people; [...] For example „Falun Dafa“ [...]“ Literary Studies Department of the Chinese Academy of Social Sciences (Ed.) 1999: 3-4. 


\section{Bibliography}

Altenburger, Roland (2001): “Chains of Ghost Talk: Highlighting of Language, Distancing, and Irony in He Dian". Asiatica Venetiana 6. February: 23-46.

Bois-Reymond, Claude du (1923): Dschung-Kuei. Bezwinger der Teufel. Potsdam: Kiepenheuer. Chen Duxiu 陈独秀 (1992): “You gui lun zhiyi 有鬼论质疑 (Questions and Doubts Concerning the Existence of Ghosts)”. In: Shen shen gui gui 神神鬼鬼 (Deities and Ghosts). Edited by Chen Pingyuan 陈平原. Beijing: Renmin wenxue chubanshe, 1-2.

Chen, Jianguo (2009): The Aesthetics of the Beyond: Phantasm, Nostalgia, and the Literary Practice in Contemporary China. Newark: University of Delaware Press.

Chen Qin (2010): “Allegories and Appropriations of the 'Ghost': A Study of Xu Xu's Ghost Love and Its Three Film Adaptations". M.A. Thesis. The Ohio State University. https://etd.ohiolink.edu/ap/10?0::NO:10:P10_ACCESSION_NUM:osu1281931832 (05/05/2015)

Chen Xuanbo 陈旋波 (2004): Shi yu guang: 20 Shiji Zhongguo wenxueshi geju zhong de Xu Xu 时与光: 20 世纪中国文学史格局中的徐訏 (Time and Light: Xu Xu and Patterns of Twentieth-Century Chinese Literary History). Nanchang: Baihuazhou wenyi chubanshe.

Éliasberg, Danielle (1976): Le Roman du pourfendeur de démons: traduction annotée et commentaires. Paris: Collège de France, Institut des hautes études chinoises.

Greene, Maggie (2012): “A Ghostly Bodhisattva and the Price of Vengeance: Meng Chao, 'Li Huiniang', and the Politics of Drama, 1959-1979”. Modern Chinese Literature and Culture 24.1: 149-199.

Hu Shi 胡适 (2003a): “Women zou na tiao lu 我們走那條路 (Which Path Will We Take?)”. In: Hu Shi Quanji 胡適全集 (Collected Works of Hu Shi). Hefei: Anhui jiaoyu chubanshe 4: $456-470$.

Hu Shi 胡适 (2003b): “Zhengli guogu yu ‘dagui'-gei Hao Xu xiansheng xin 整理国故与 ‘打鬼” 给 浩徐先生信 (The Organization of National Heritage and 'Beating Ghosts'-a Letter to Mr. Hao Xu)”. In: Hu Shi Quanji. Hefei: Anhui jiaoyu, 3: 144-155.

Imbach, Jessica (2014): “Ghost Talk in 1936: 'Living Ghosts' and 'Real Ghosts' in Republican-Era Literary Discourse and the Two Analects Fortnightly Ghost Story Special Issues”. Journal of Modern Literature in Chinese 12.1: 14-45.

Li Zeng (2009): “Horror Returns to Chinese Cinema: An Aesthetic of Restraint and the Space of Horror”. Jump Cut: A Review of Contemporary Media 51: 1-12.

Liang Shiqiu 梁实秋 (1936): “Lüe tan shashibiya zuopin li de gui 略谈莎士比亚作品里的鬼 (Some Remarks on Ghosts in Shakespear's Works)”. Lunyu banyuekan 92: 950-951.

Liu Jianmei (2002): "Shanghai Variations on 'Revolution Plus Love”. Modern Chinese Literature and Culture 14.1: 51-92.

Liu Shengya 刘盛亚 (1949): Diyumen 地狱门 (Gates of Hell). Shanghai: Chunqiu chubanshe. Lu Xun 鲁迅 (1987a): “Sanshisan 三十三 (Thirty-Three)”. In: Lu Xun quanji 鲁迅全集 (Complete Works of Lu Xun). Beijing: Renmin wenxue chubanshe, 1: 298-304.

Lu Xun (1987b): “Wusheng de Zhongguo 无声的中国 (A Voiceless China)”. In: Lu Xun quanji. Beijing: Renmin wenxue chubanshe, 4: 11-15.

Lu Xun (1987c): “Xinqingnian bi du shu 新青年必读书 (Necessary Readings for the Youth)”. In: Lu Xun quanji. Beijing: Renmin wenxue chubanshe, 3: 12-13.

Ma Zihua (1936): “Gui yu nüxing 鬼与女性 (Ghosts and Femininity)”. Lunyu banyuekan 92: 955-958. 
Meng Yue (1993): “'Baimaonü’ yanbian de qishi - jianlun Yan’an wenyi de lishi duozhixing 〈白毛女〉演变的启示 - 兼论延安文艺的历史多质性 (The Transformations of “The WhiteHaired Girl' and Its Significance: On the Polyphony of History in Yan'an Literature)”. In: Reinterpretation: Popular Literature and Ideology. Edited by Tang Xiaobing. Hong Kong: Oxford University Press, 63-89.

Mu-chou poo (2004): “The Concept of Ghost in Ancient Chinese Religion”. In: Religion and Chinese Society, Vol.1. Edited by John Lagesweg. Hong Kong: The Chinese University Press, 173-191.

Mu Shiying 穆时英 (1996): Zhongguo xinganjuepai shengshou: Mu Shiying xiaoshuo quanji 中国新感觉派圣手: 穆时英小说全集 (The Master of Chinese Neo-Sensationalism:

The Collected Novels of Mu Shiying). Beijing: Zhongguo wenlian.

Ng, Andrew Hock Soon (2007): Interrogating Interstices: Gothic Aesthetics in Postcolonial Asian and Asian American Literature. Bern: Peter Lang.

Ouyang Shan 欧阳山 (1988a): “Gao Ganda 高干大 (Uncle Gao)”. In: Ouyang Shan Wenji 欧阳山 文集 (The Collected Works of Ouyang Shan). Guangzhou: Huacheng, 4: 1477-1711.

Ouyang Shan (1988b): “Guichao 鬼巢 (Ghost Nest)”. In: Ouyang Shan Wenji. Guangzhou: Huacheng, 2: 594-659.

Pang, Laikwan (2011): “The State Against Ghosts: A Genealogy of China's Film Censorship Policy”. Screen 52.4: 461-476.

Shao Xunmei 邵洵美 (2012): Ziyou tan 自由谭 (Candid Talk). Shanghai: Shanghai shudian chubanshe.

Shi Jimei 施济美 (1998): Shi Jimei xiaoshuo: Fengyi yuan 施济美小说: 凤仪园 (Shi Jimei's Novels: Fengyi Garden). Edited by Ke Ling 柯灵. Shanghai: Shanghai guji chubanshe.

Shi Zhecun 施搵存 (1996): Shinian chuangzuoji 十年创作集 (A Collection of Ten Years of Creative Works). Shanghai: Huadong shifan daxue.

Su Tong 苏童 (1993): “Yishi de wancheng 仪式的完成 (The Completion of the Ritual)". In: Shaonian xue 少年血. (Young Blood). Su Tong Wenji 苏童文集 (The Collected Works of Su Tong). Nanjing: Jiangsu wenyi, 214-223.

Tang Xuehua 汤雪华 (1993): “Mi 迷 (Riddle)”. In: Yuanyang hudie Pai Yanqing Xiaoshuo Jicui 㽜 莺蝴蝶派言情小说集粹 (下册) (Essential Collection of Love Stories from the Mandarinduck and Butterfly School, Vol. 3). Edited by Xiang Yannan 向燕南 and Kuang Changfu 匡长福. Beijing: Zhongyang minzu xueyuan chubanshe, 1355-1373.

The Institute of Literature of the Chinese Academy of Sciences (1961): Stories About Not Being Afraid of Ghosts. Peking: Foreign Language Press.

Wang, David Der-wei (1997): Fin-de-Siecle Splendor: Repressed Modernities of Late Qing Fiction, 1848-1911. Stanford: Stanford University Press.

Wang, David Der-wei (2004): The Monster That Is History: History, Violence, and Fictional Writing in Twentieth-Century China. Berkeley/Los Angeles/London: University of California Press.

Wang Lan 王蓝. (1944): Guicheng ji 鬼城记 (Tales from Ghost City). Chongqing: Honglan chubanshe.

Wedell-Wedellsborg, Anne (2005): “Haunted Fiction: Modern Chinese Literature and the Supernatural”. International Fiction Review 32.1. http://journals.hil.unb.ca/index.php/IFR/ article/view/7797/8854 (04/05/2015)

Xiao Xiangming 肖向明 (2006): “Lun xin wenhua yujing xia 'gui' de wenxue cunzai 论新文化语 境下 “鬼” 的文学存在 (On Literary “Ghosts' in the Context of the New Culture Movement)”. Jinyang Xuekan 5: 103-109. 
Xiao Xiangming 肖向明 (2009): “'Guiyu-renjian’ de zhengzhi yuyan-Lun 20 Shiji 40 niandai 'minjian xinyang' de wenxue xiangxiang ‘鬼域 - 人间' 的政治寓言 - 论 20 世纪 40 年代 ‘民间信仰”的文学想象 (The Realms of Ghosts and Humans as Political

Allegories - on the Literary Imagination of 'Popular Religiosities' in the 1940s)". Hainan shifan daxue xuebao (shehui kexue bao): 12-17.

Xu Xu 徐訏 (1936): “Guixi 鬼戏 (Ghost Play)”. Lunyu banyuekan 91: 919-920.

Xu Xu (1937): “Guilian 鬼恋 (Ghost Love)”. Yuzhou Feng 1-2: 444-448; 488-493.

Xu Xu (1943): Guilian. Chengdu: Dongfang shushe.

Xu Xu (1996): “Guilian”. In: Haipai xiaoshuo jingpin 海派小说精品 (Selected Stories of the Shanghai School). Edited by Wu Huanzhang 吴欢章. Shanghai: Fudan daxue chubanshe.

Yang Yi 杨义 (1998): Zhongguo xiandai xiaoshuo shi (xia) 中国现代小说史 (下) (A History of Modern Chinese Fiction, Vol.3). Beijing: Renmin wenxue chubanshe.

Ye Lingfeng 叶灵风 (1999): “Luoyan 落雁”. In: Aiqing Lioazhai 爱情聊斋 (The Liaozhai of Love). Edited by Wang Aisong 王爱松 and Shao Wenshi 郡文实. Beijing: Kunlun chubanshe, 1-13.

Yuan Changying 袁昌英 (1947): “Niu 牛 (Buffalo)”. In: Wuti ji 无题集 (Untitled). Edited by Zhao Qingge 赵清阁. Shanghai: Chenguang chuban gongsi, 1-26.

Zeitlin, Judith T. (2007): The Phantom Heroine: Ghosts and Gender in Seventeenth-Century Chinese Literature. Honolulu: University of Hawaii Press.

Zhang Henshui 张恨水 (1993): Xin zhangui zhuan 新斩鬼传 (New Account of Ghost Beheading). Taiyuan: Beiyue wenyi chubanshe.

Zhang Kebiao 章克标 (1999): “Shenlou 傆楼 (Mirage)”. In: Aiqing Lioazhai 爱情聊斋 (The Liaozhai of Love). Edited by Wang Aisong 王爱松 and Shao Wenshi 邵文实. Beijing: Kunlun chubanshe, 14-33.

Zhang Lianhong 张炼红 (2013): Lilian jinghun: Xin Zhongguo xiqu gaizao kaolun 历练精魂: 新中 国戏曲改造考论 (Improving the Spirits: A Historical Study of Theater Reform in New China). Shanghai: Shanghai Renmin Chubanshe.

Zhang Taiyan 章太炎 (1982): “Da Tie Zheng 答铁铮 (Reply to Tie Zheng)”. In: Zhang Taiyan Quanji 章太炎全集 (Collected Works of Zhang Taiyan). Shanghai: Shanghai renmin, 4: $369-375$

Zhang Tianyi 张天翼 (1931): Guitu riji 鬼土日记 (Ghostland Diary). Shanghai: Zhengwu shuju. Zhongguo kexueyuan wenxue yanjiusuo 中国社会科学院文学研究所 (ed.) (1961): Bu pa gui de gushi 不怕鬼的故事 (Stories About Not Being Afraid of Ghosts). Beijing: Renmin wenxue chubanshe.

Zhongguo shehui kexueyuan wenxue yanjiusuo (ed.) (1999): Bu Pa Gui de Gushi. Beijing: Renmin wenxue chubanshe.

Zhou Libo 周立波 (1979): Zhou Libo duanpian xiaoshuo ji 周立波短片小说集 (Zhou Libo's Short Stories). Beijing: Zhongguo qingnian chubanshe.

Zhou Zuoren 周作人 (1992): “Jiuxi yinxiang (er) 旧戏印象 (二) (Old Opera Impressions (two))”. In: Zhou Zuoren Sanwen 周作人散文 (Collected Essays of Zhou Zuoren). Beijing: Zhongguo guangbo dianshi chubanshe, 4: 469-470. 